\title{
Migration, the Shadow Economy, and Parallel Legal Orders in Russia
}

Traditionally seen as a country of emigration, Russia has become one of the main migration hubs worldwide following the collapse of the Soviet Union. Thus, two dominant trends emerge when analyzing Russia's post-Soviet immigration history. In the 1990s, migratory flows to Russia were characterized largely by forced migration, where more than 10 million people, predominantly "ethnic" Russians, returned to Russia owing to political instability and rising nationalism in the former Soviet republics (Laruelle 2007). An extensive body of scholarly literature focused on the forced migration and resettlement of ethnic Russians and other Russian-speaking communities to their ethnic homeland (Messina 1994; Pilkington 1998; Pilkington and Flynn 2006; Flynn 2007). Soon after the turn of the century, however, economic factors affected the volume, whereby large-scale labor migration became the dominant trend (Demintseva 2017). These migratory processes were driven largely by the rapidly growing Russian economy and the declining working-age population, on the one hand, and economic stagnation, poverty, high unemployment rates, and extremely low salaries in other post-Soviet republics, on the other (Denisenko and Chernina 2017). Migrant labor represented the primary source available to make up for shortages in the domestic labor force and to meet the needs of Russia's oil-fueled construction boom. Another contributing factor to the massive labor migration was the visa-free border regime under a Commonwealth of Independent States (CIS) agreement that allowed the citizens of most post-Soviet republics to enter Russia without restrictions (Abashin 2014). Thus, a distinctive feature of the migratory processes in the first decade of the new millennium, compared to the 199os, was the massive influx of migrant labor, which transformed Russia into the world's third-largest recipient of migrants (after the United States and Germany), whereby 11.6 million foreign-born individuals resided in its territory (UNPD 2015). 
International migrants are thus an integral component of the Russian labor market, contributing 16 percent to Russia’s labor force (World Bank 2011). Every large-scale state-funded program-including infrastructure and construction projects such as the Moscow International Business Center (also known as Moskva-City), the 2018 FIFA World Cup Russia, or the 2014 Winter Olympic Games in Sochi-depends heavily on the migrant labor force. Large Russian cities, such as Moscow, Saint Petersburg, Novosibirsk, Krasnodar, Tyumen, and Yekaterinburg, serve as the primary magnets for migrants (Streltsova 2014). The vast majority of migrant workers come to Russia from three Central Asian countriesKyrgyzstan, Tajikistan, and Uzbekistan (Malakhov 2014). ${ }^{1}$ Because Russia maintains a visa-free regime with the CIS states, almost all migrants from Central Asia enter Russia legally and become undocumented only after failing to obtain a work permit and residence registration. The average Central Asian migrant is a young male with a secondary education and a poor command of the Russian language, originating from the rural areas or small towns of Central Asia where unemployment rates remain exceptionally high (Laruelle 2007; Abashin 2014). Men constitute 80 to 90 percent of migrants from Tajikistan and Uzbekistan, whereas almost half of the migrants from Kyrgyzstan are female (Marat 2009; Tyuryukanova 2011; FMS 2015). Central Asian migrants work primarily in construction, trade, transportation, service, agriculture, and housing and communal services (Malakhov 2014). Female migrants typically work in supermarkets and small shops, cafés and restaurants, and bazaars, as well as in domestic venues and the cleaning sectors (Tyuryukanova 2011). Owing to the high cost of accommodation and precarious working conditions, migrants rarely bring their family members to Russia. Members of a migrant's immediate family remain at home, and the migrant typically sends his earnings home to provide for their daily needs and other expenses, such as building a new house or purchasing a car, or to pay for life-cycle rituals, medical treatment, and education (Urinboyev 2017a).

No reliable statistics are available on the number of migrant workers in Russia. According to the General Administration for Migration Issues of the Ministry of Internal Affairs of the Russian Federation, as of November 2016, 10.2 million foreign citizens and stateless persons were legally residing in Russia (RBK 2016). Nearly 4 million of these foreigners were citizens of Central Asian countries: 1.9 million people from Uzbekistan, 1.06 million people from Tajikistan, and 620,000 people from Kyrgyzstan (RANEPA 2019a, 2019b). But Russian government statistics count only the number of foreign citizens who crossed the border and entered the country legally; they do not include the several million undocumented migrant workers currently in Russia (Denisenko 2017). Since undocumented migrants are not included, the official statistics underestimate the number of immigrants in Russia. For example, in 2016, 4 million people stated on their migration card that they were entering Russia for "employment," but only 2 million people received work permits, implying that those who did not gain work documents found 


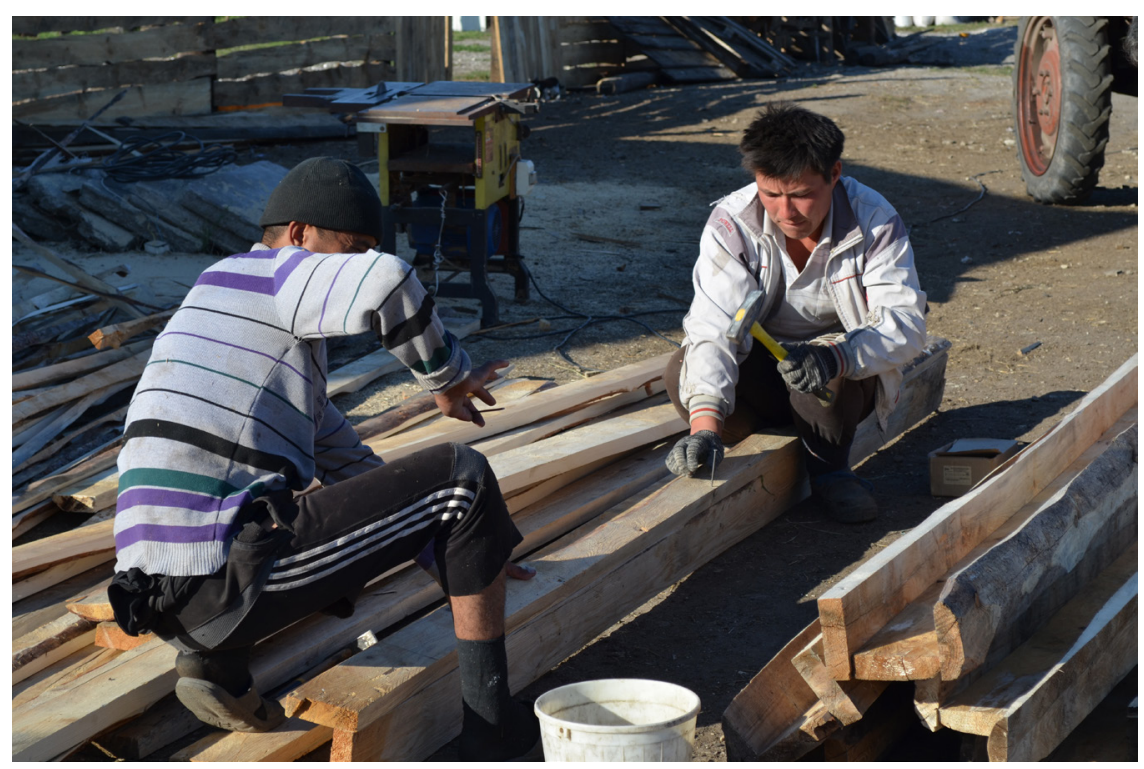

FIGURE 3. Uzbek construction workers in Moscow, Russia. September 2014. Photo by author.

employment in the shadow economy (RBK 2016). In addition, Russian government statistics are based on officially reported work permits (including migration patents), meaning citizens of member countries belonging to the Eurasian Economic Union are not included in these statistics, since they are not legally required to obtain a migration patent (Denisenko and Chernina 2017). Given these complexities, it is unsurprising that no consensus exists among migration scholars and experts regarding the number of migrants in Russia. That is, the figures vary, placing the number of migrants living in Russia at 9 to 18 million individuals depending on the source used (cf. Reeves 2015; Abashin 2016; Schenk 2018).

An analysis of labor migration trends in Russia since the early 2000 indicates that movement between Central Asia and Russia seems to be well-established and resilient. When the economic crises hit Russia in 2009 and 2014, Russian media outlets quickly announced that Central Asian migrants were leaving Russia as a result of the recession. Initially, the number of migrants indeed decreased considerably. But Russia quickly returned to its position as the primary migration hub for Central Asian migrants given the absence of reintegration policies and economic opportunities in their home countries. Even the introduction of draconian immigration laws and policies did not significantly reduce the number of migrants, instead pushing them into the shadow economy. Within that shadow economy migrants produced a parallel legal order to regulate their daily workinglife and socioeconomic practices. These processes are described in the sections that follow. 


\section{DEVELOPMENT OF IMMIGRATION LAWS AND}

\section{POLICIES IN RUSSIA}

The development of immigration laws and policies in Russia can be divided into two periods: (a) the 199os and (b) 2000 to the present. An analysis of immigration laws and policies adopted during these two periods indicates that Russian migration policy underwent significant transformations from a single Soviet citizenship and identity toward increasing control over the immigration flows and the tightening of immigration laws and policies (Malakhov 2014; Abashin 2016; Schenk 2017; Kuznetsova and Round 2018).

The first migration laws adopted in the 1990s (the Federal Law on Refugees and the Law on Forcibly Displaced Persons) focused on forced migrants and refugees (predominantly "ethnic Russians") who arrived in Russia from other former Soviet republics owing to the collapse of the USSR. Those laws aimed primarily to facilitate the return of forced migrants and refugees to Russia through the introduction of simplified procedures to receive refugee status or a permanent residence permit in Russia. Another key legislative action in the 1990 os focused on passing several decrees and laws on "compatriots abroad." These decrees and laws aimed to support individuals who formerly held USSR citizenship and resided in countries once a part of the USSR who wished to maintain their ties and loyalty to postSoviet Russia. Because the concept of "compatriot" was broadly defined within the law, anyone who lived in the post-Soviet space could claim to be a "compatriot," move permanently to Russia, and eventually receive Russian citizenship (Abashin 2016). The immigration laws of the 199 os were thus ad hoc, piecemeal, and liberal in the sense that they served primarily to regulate the return of ethnic Russians and other Russian-speaking communities from the newly independent states of the former Soviet Union (Schenk 2018).

Following the onset of the massive labor migration from Central Asia to Russia in the early 200os, Russian migration policy and the official rhetoric toward citizens of former Soviet republics shifted significantly. Given that Russia received millions of migrant workers from Central Asia and the Caucasus during a relatively short period, both the Russian public and politicians appeared largely unprepared to face the new reality of Russia becoming a country of immigration (Malakhov 2014). During the initial period of the Central Asian labor migration to Russia, no clear-cut migration policy or strategy existed, and the legal frameworks to regulate labor migration remained at an embryonic stage (Nikiforova and Brednikova 2018). These large-scale migratory processes coincided with political instability in Chechnya and global developments associated with the emerging war on terrorism, which increased security concerns among Russian policy makers and subsequently influenced the design of the resulting immigration laws and policies (Schenk 2018). The adoption of a new law in 2002, "The Law on the Legal Status of Foreign Citizens in the Russian Federation," represented one of the first 
serious attempts of the Russian authorities to regulate the flows of immigration based on a "preferred vs. non-preferred migrants" rationale (Abashin 2016). That law significantly tightened the ethnic and cultural requirements for foreign citizens seeking to secure a permanent residence permit and Russian citizenship. The legal status of foreign citizens was then determined based on (a) the country of origin, (b) the presence or absence of a visa, (c) the length of stay, (d) the purpose of the visit, (e) the type of employer (public, private, or individual), (f) the absence or presence of an employment contract or work permit, and (g) family status. New migration management mechanisms, such as a migration card, visa procedures, quotas for temporary residence permits and work permits for foreigners from visa countries, and requirements for registration at a place of accommodation, were introduced. These legislative changes clarified the migration status of foreign citizens and unified procedures for registering and issuing work permits (Denisenko and Chernina 2017).

Yet despite Russian authorities' attempts to coherently regulate labor migration, these new procedures for obtaining work permits emerged as too complex, unclear, and contradictory for visa-free migrants from CIS (post-Soviet) countries. While the law clearly described the procedures employers must follow to hire a worker from a visa country, no separate procedure was described for the hiring of migrants from visa-free countries. This meant that all migrant workers from CIS countries remained completely dependent on their employers to submit the documents required for legal work status (Schenk 2018). This ambiguity explains why millions of migrant workers from CIS countries resorted to the shadow economy, where they could work without any type of work permit. Another factor enabling migrants to operate in the shadow economy was the possibility of crossing the border visa-free and remaining in Russia for up to 90 days, which could be easily prolonged by leaving the country and immediately returning. Before the expiration of their 90-day stay, migrants typically traveled to the Russia-Ukraine or the Russia-Kazakhstan border to renew their migration card, thus allowing them to stay legally in Russia for another 90 days in accordance with the Law on the Rules of Entry and Exit from the Territory of the Russian Federation of 1996 (revised in 2012 and 2013). According to expert estimates, 3 to 5 million migrants worked in the shadow economy from 2002 through 2005 (Ivakhnyuk 2006; Tyuryukanova 2008; Krasinets 2009), while the number of undocumented migrants reached fewer than 1 million individuals in the period between 1999 and 2000, when labor migration remained largely unregulated (Zayonchkovskaya 2000).

These developments sent shockwaves rumbling across Russia and led to the widespread perception both among state officials and among the general public that immigration was out of control. In response the Security Council of Russia held a meeting on migration in 2005, at which Putin (2005) pointed to "notorious administrative barriers" and "chronic bureaucratic diseases" as the primary factors pushing migrants into the shadow economy. He called for a revision and 
modernization of Russia's immigration laws. Following Putin's critique, an interdepartmental working group was established under the leadership of the Ministry of Internal Affairs, resulting in several amendments to the "Law on the Legal Status of Foreign Citizens" in 2006 (Ivakhnyuk 2013). On the one hand, the amendments simplified the legalization procedures for migrants from CIS countries in terms of registering at the place they lived or worked, applying for a work permit on their own, and moving among different employers. On the other hand, new restrictions regarding work permit quotas were introduced for citizens of post-Soviet countries. Under this new immigration legal environment, CIS migrants had two options available to them for acquiring a work permit. The first option relied on securing a work permit through an employer, who applied for a quota allocation during the previous year. The second option required migrants to obtain a work permit independently, either by applying for a permit on their own or by applying through an intermediary. These aspects of the law were viewed as a shift toward liberalizing the Russian immigration policy, since migrants could obtain work permits on their own and move freely among employers (Schenk 2018). Owing to a quota of 6 million work permits for 2007, many migrants legalized their status, and the number of documented migrants increased from 570,000 in 2006 to 2.4 million in 2008 (Denisenko and Chernina 2017). More than half of these work permits were issued to citizens of Kyrgyzstan, Tajikistan, and Uzbekistan (Zayonchkovskaya and Tyuryukanova 2010).

Following the 2008-9 economic crisis, however, the Russian migration regime again shifted dramatically. That crisis led to a decrease in the total flow of migrant workers by approximately 15 to 20 percent (Zayonchkovskaya and Tyuryukanova 2010). Consequently, Russian authorities also reduced the work permit quota from 6 million in 2007 to 3.4 million in 2008 (Denisenko and Chernina 2017). Apparently, the decision to reduce the quota was made without a careful evaluation of the shifting demand for a foreign labor force. Because Russia quickly recovered from the economic crisis, the total flow of migrants returned to its previous levels. Yet, despite these trends, the quota continually decreased year by year (standing at 1.6 million in 2014 in its final year), pushing migrants into the shadow economy (Schenk 2018). This decrease was largely due to the legal requirement that every employer must submit applications to regional authorities by May each year, indicating their need for a certain number of foreign workers with specific skills and qualifications. Thus, the size of the yearly quota was determined in accordance with the number of applications submitted by employers. Many entrepreneurs, however, particularly small business owners, were ineligible within such quotas owing to the complicated bureaucratic procedures and legal restrictions. Even the introduction of "out-of-quota" work permits (known as a "patent") in 2010 did not significantly improve the situation, since patents were only valid for migrants entering into employment with individual citizens for personal, household, and other nonbusiness purposes. As a result, many were forced to operate in 
the shadow economy, hiring migrants without any work documents (Denisenko and Chernina 2017). From their side, millions of CIS migrants-predominantly Central Asian migrants-continued their established practice of prolonging their stay in Russia by renewing their migration card at a nearby border before the expiration of the 90-day grace period.

As an antidote to the constantly expanding shadow economy fueled by an undocumented migrant labor force, Russian authorities further tightened the laws, strengthened the border infrastructure, and introduced highly punitive measures. The Concept of the State Migration Policy 2025, adopted in 2012, clearly outlined the concerns of Russian authorities over continually increasing irregular migration, calling for the need to combat "illegal migration" through a refinement of the penalties for violations to migration legislation, developing the immigration control infrastructure, and improving the operation of special institutions to detain foreign nationals and stateless persons (Abashin 2016; Kondakov 2017). Consequently, between 2012 and 2015 Russian authorities adopted more than 50 laws and regulations aimed at reducing undocumented migration through severe administrative and criminal penalties for violation to migration laws (Denisenko 2017). The most visible evidence of these new tendencies was the introduction of an entry ban (zapret na v'ezd). In 2013 Russian authorities introduced the entry ban as an immigration law sanction and began applying it to foreign citizens who violated the conditions on the length of stay, migration, and employment regime. In July 2013 more severe amendments were made to the entry-ban legislation, according to which the three-year entry ban was to be issued to foreign citizens who had committed two or more administrative offenses within a period of three years (Kubal 2016a). Administrative law violations included offenses such as speeding or illegal parking, violations to highway codes, living in a place not indicated in the official residence registration, or not being able to present a valid identification document when stopped by the police. The three-year entry ban could be issued to a foreign citizen who committed two administrative law violations during their stay in Russia. The entry ban was typically issued by a staff member of the Main Directorate for Migration Issues of the Ministry of Internal Affairs (formerly the Russian Federal Migration Service) after cross-referencing the police databases for petty administrative offenses with the database containing information about foreign citizens' residence status in Russia (Kubal 2016a). ${ }^{2}$ In addition to the entry ban, another new law, known as the "90-180 rule," came into effect in January of 2014, stipulating that foreigners can stay in Russia for only 90 days within any 180 -day period. These restrictions made it impossible for migrants to cross the border every three months and reenter Russia beginning a new grace period. New sanctions were introduced to ensure migrants' compliance with the "90-180 rule." Accordingly, migrants who stayed illegally for more than 270 days were subsequently banned from entering Russia for 10 years, whereas those who overstayed by 170 to 270 days could not enter the country for five years, and those 
who overstayed less than 170 days were not allowed to enter Russia for three years (Denisenko 2017).

The Russian migration regime underwent a further significant transformation in 2014 and 2015. One of the key changes included abolishing the system of work permit quotas for citizens from visa-free countries in 2015 and the introduction of a single patent system that covered all forms of migrant employment. Until 2015, migrants could use the patent only for entering into employment with individual citizens for personal, household, or other similar purposes. As of January 1, 2015, however, patents became the main channel for legal employment for all foreign workers (including CIS citizens) entering Russia under the visa-free regime, regardless of whether they worked for an organization, individual entrepreneur, or individual. ${ }^{3}$ To obtain a patent, migrants must complete numerous requirements within 30 days of their arrival. These include (1) holding a migration card, received at the border, upon which the purpose of entry to the Russian Federation must be indicated as "work"; (2) proof of residence registration; (3) a certificate verifying that they have passed a Russian-language, law, and history exam; (4) a medical certificate clearing them of drug addiction and infectious diseases such as tuberculosis, HIV, etc.; (5) proof of medical insurance obtained through their employers or purchased from a private insurance company approved by the regional government; (6) a receipt indicating payment of patent fees and first month's taxes; and (7) a translated and notarized copy of a valid passport. Patents are typically issued for a period of between 1 and 12 months, after which they can be renewed for another 12 months. The introduction of a single patent system was put forward as a liberal turn in the Russian immigration legislation, which would enable many migrants from Central Asian countries to legalize their work status. This would primarily benefit individuals previously unable to obtain a work permit because of the shortage of quotas and complicated bureaucratic procedures. Konstantin Romodanovski, head of the former Federal Migration Service (FMS), was quick to declare that the number of legally employed migrants exceeded the number of undocumented migrants for the first time ever (Romodanovski and Mukomel 2015).

Another significant change in the Russian migration regime features a steady move toward a "policing" approach to migration management. This is particularly visible in the transformation of the FMS from an independent civic structure to a law-enforcement agency. FMS was established in 1992 on the basis of the Committee for Migration Affairs under the Ministry of Labor and Employment of the Russian Federation. As an independent civic institution, FMS's initial task was to regulate the return of ethnic Russians and Russian-speaking refugees from the post-Soviet republics to Russia. At the beginning of the 2000 s, however, when the inflow of Russian-speaking migrants began decreasing and was gradually replaced by the growing influx of Central Asian and Caucasian migrants, FMS was reorganized to regulate external labor migration. Although FMS was dissolved, recreated, 
and reorganized several times between 2000 and 2016, oscillating between a law-enforcement agency and a civic structure, in reality it represented an autonomous, powerful bureaucratic structure with its own central management apparatus, hierarchies, and regional offices. As Abashin (2016) notes, despite its significant flaws, the concentration of resources and power to manage migration processes within one institution, FMS allowed for the consolidation of migration policy and created the conditions for reviewing migrant legalization issues from a more liberal point of view. The sudden decision to abolish FMS and the transfer of its migration regulation functions to the Ministry of Internal Affairs marked a significant shift in the Russian migration regime. As a result of this shift, migration service officials became de facto "police officers without uniforms." Consequently, migration policy lost its independent civic character and fell once again under the main law-enforcement agency, viewing migrants as potential illegal aliens posing a threat to the public order and security (Nikiforova and Brednikova 2018).

\section{THE IMPACT OF IMMIGRATION LAWS AND POLICIES ON THE FORMATION OF THE SHADOW ECONOMY}

As shown in the previous section, the Russian migration regime is characterized by numerous legal inconsistencies and ambiguities. Because formal rules and requirements for the residence and employment of foreign citizens are complex, volatile, and constantly changing, most migrants can barely follow or understand the legislative changes. Migrants typically rely on their social networks as a source of information about such changes, but this information is often based on rumors and false knowledge. Even lawyers from human rights nongovernmental organizations find it difficult to fully understand Russia's immigration laws and bureaucratic procedures (Malakhov and Simon 2017). This also rings true for migration service officers, who begin their daily work by monitoring the FMS website to check the latest news and amendments to immigration laws (Nikiforova and Brednikova 2018). Given that the majority of migrants entering Russia are not well-educated, do not speak Russian, have poor knowledge of laws, and originate from the rural areas of Central Asia, it is highly unlikely that they can comply with the fluid immigration laws and operate legally within the labor market. Furthermore, migrants must deal with the arbitrary actions of police officers, migration officials, and border guards always seeking ways to exploit legal ambiguities and cumbersome bureaucratic procedures to generate informal benefits (Malakhov and Simon 2017). Consequently, the ambiguous and arbitrary nature of immigration laws and practices generates an immigration legal regime that pushes masses of migrant workers into domains of illegality, rendering shadow economy employment the only viable option.

Although the Russian authorities continually introduce draconian laws and develop the immigration control infrastructure, the Russian migration regime is 
plagued by corruption and a weak rule of law (Light 2010; Malakhov 2014; Schenk 2018). Thus, the implementation of such laws remains arbitrary and can be used by state officials to generate informal benefits. An extensive literature demonstrates the different dysfunctionalities of the Russian legal system (McAulley, Ledeneva, and Barnes 2006; Hendley 2012; Ledeneva 2013). Likewise, immigration laws are simply emblematic of the "unrule of law" culture in Russia (Gel'man 2004), characterized by the prevalence of informal rules and norms over formal institutions. Under these circumstances the more restrictive the immigration laws are, the higher the rate of informal payments migrants must make to Russian police officers, migration officials, and border guards to continue working in Russia. In other words corruption is the primary factor determining current immigration politics, given that the actions of a considerable number of Russian officials are driven not by legal-rational logic but by the logic of material interests (Malakhov 2014). In practice, then, even those migrants who possess all of the required paperwork cannot be certain that they are fully "legal" and that they will not experience problems when stopped by Russian police officers and migration officials (Reeves 2015; Round and Kuznetsova 2016). Thus, a "legal" or "illegal" status hinges on contextual factors, such as how, when, and where the interaction between migrants and Russian state officials takes place, as well as on individual factors, such as migrants' knowledge of informal rules and their ability to adapt to the legal environment (their street smarts and ability to find common ground [obshchii iazyk]) with state officials, bribery skills, and connections with street institutions, such as intermediaries and racketeers). Hence, the only path to becoming "legal" requires the use of various semilegal and outright illegal practices (Dave 2014a). These specifics of the Russian legal system give rise to a specific legal adaptation strategy, where migrants are required to master the informal rules and street laws. They must also develop the skills necessary to negotiate with informal channels to access employment, housing, social services, and other opportunities typically limited to those with legal status or hard to obtain in the current legal framework of the host country.

The informal practices surrounding residence registration provide an illustrative example. Despite the existence of a visa-free regime, Central Asian migrants are required to obtain residence registration within seven days of arrival in Russia. This procedure, referred to as registratsiia in migrants' everyday language, originates from the infamous Soviet practice of the propiska system, representing one of the main barriers to migrant legalization in contemporary Russia. Particularly problematic is that it is quite difficult for a typical migrant worker to find an apartment and a landlord willing to register him or her at that apartment address. It is especially difficult to obtain registration in big cities such as Moscow or Saint Petersburg, where the majority of migrants are concentrated. This process became more difficult following the adoption of the so-called law on rubber apartments in 2013, which made it illegal to register a large number of foreign citizens at the same address. As Malakhov and Simon (2017) note, the very design of this law 
was far removed from reality and open to corruption, given that migrants' average monthly salary is between 15,000 and 25,000 rubles (US\$250-\$400), whereas the average monthly rental costs range from 30,000 to 40,000 rubles (US\$450-\$650) for a modest two- to three-room apartment in the suburbs of Moscow. Because of their meager income, migrants usually buy a koiko mesto (mattress-sized sleeping space) for 4,000 to 5,000 rubles per month (US\$60-\$80) in an apartment shared by 15 to 20 people. The koika-mesta arrangements, while illegal, represent an inalienable part of migrants' daily lives in Russia. Given their illegal residence, migrants cannot obtain a registration at the address where they live. As a result, they are forced to buy a "clean fake" registration for a fee of 2,500 to 3,000 rubles for three months from private agencies and intermediaries well-connected to state officials. As Reeves (2013) describes, typically such "clean fake" registration addresses exist somewhere in the city and can be found in the official database when checked by the police, yet migrants never live there and have no connection to that building or its residents. This reality is an open secret among both migrants and state officials in Russia. Thus, when stopped by the police, migrants are vulnerable to being caught and fined for violating residence laws. Under these circumstances it is crucial that migrants act street smart and "perform" residence at their fictive address by knowing how to get there, which metro stations are located nearby, and the general details about the building. Having a "legal" residence depends largely on migrants' street smartness and their ability to play by the rules of the game.

Introduced in $\mathbf{2 0 1 5}$ as a replacement for the work permit system, the new patent system became more problematic than the previous quota system. In practice, the new patent system primarily aimed to simplify the legalization of the work and residence registration status such that migrants could "come out of the shadows" and work legally. Despite its liberal nature, however, the patent system introduced complicated bureaucratic procedures and high legalization fees that further pushed migrants into the shadow economy (Heusala 2018). Within 30 days of arrival migrants are required to complete numerous procedures, such as pass language tests, obtain a medical examination, secure health insurance, acquire residence registration, and pay various fees. Thus, it is exceptionally difficult to complete all the procedures within the 30-day period, both from a bureaucratic and a financial standpoint. On average the cost of all these tests, the medical examination, the insurance plan, and the general fee for the patent reach approximately 25,000 rubles (about US $\$ 400$ ), placing a heavy financial burden on migrants who have just arrived with little or no money (Nikiforova and Brednikova 2018). After obtaining a patent, migrants are required to pay a monthly fee for the patent, the amount of which depends on the region in which the migrant works (e.g., 5,00o rubles [US\$80] for Moscow). Until 2014 the monthly patent fee was 1,000 to 1,200 rubles (US\$15-\$18), a reasonable and affordable sum. But the fee increased to 4,000 to 5,000 (US\$60-\$80) rubles after 2014 . In addition to paying a monthly fee, migrants must renew their residence registration every three 
months, each time costing 3,000 rubles (US\$30-\$45). Until 2015 migrant's residence registration was automatically prolonged for the period during which the patent was valid. Beginning in January of 2015, however, migrants were required to renew their registration every three month via intermediaries. All of these legalization expenses fall well beyond the financial capacity of migrants, given their meager incomes. Even those migrants who received a patent find it hard to remain "legal" and eventually resort to the shadow economy. This is because a migrant's average monthly salary is 25,000 rubles, a sum significantly lower than the salary of Russian citizens. In addition to the monthly patent fee (5,000 rubles), migrants have food (3,000 rubles), accommodation (5,000 rubles), and transport (1,000 rubles) expenses. On top of these expenses they must send money home, which is the main motivation bringing them to Russia. If migrants pay the monthly fee and work legally, they can send about 10,000 to 11,000 rubles (US\$150-\$70) home. It is also possible to earn up to US $\$ 150$ per month in Central Asia; the only reason drawing migrants to Russia is the motivation to earn more money than at home. Consequently, these expensive legalization procedures further push migrants into the shadow economy, where they can work without any documents (Kuznetsova and Round 2018; Schenk 2018).

These restrictive immigration laws and policies also led to the proliferation of a diverse set of legally fictitious spaces and illegal document schemes that generated informal benefits for the various state officials and intermediaries closely linked to the police and law-enforcement officials (see Reeves 2013; Dave 2014a). To cope with this restrictive legal environment, migrant workers normally approach numerous intermediaries (posredniki) who can provide various fake (fal'shivka), "clean fake" (chistaya fal'shivka), and "almost clean" (pochti chistiy) residence registrations, patents, and temporary and permanent residence permits, as well as fake Russian and Kyrgyz passports. One can easily spot numerous intermediaries (with a migrant background) in Moscow's Kazansky railway station and in air ticket offices (aviakassi) located near various metro stations. Given that the majority of these intermediaries are migrants from Central Asia, it is apparent that they operate under some sort of "protective roof" (krysha), often provided by law-enforcement officers. This trend is substantiated by Russian government statistics, which show that the most common crimes committed by migrants are those connected with document counterfeiting (Golunov 2014). Intermediaries can also consist of a broad range of people, such as lawyers, migrants' associations, diaspora activists, and legal and commercial firms offering documentation and "legalization services" closely connected to officials within the state administration, migration services, and police and security services (Dave 2014a). Illegal schemes even extend to the embassies of Central Asian countries, which informally provide various services to migrants. ${ }^{4}$ The availability of such legally fictitious spaces and "legalization" schemes allows migrants to remain and work in Russia without authentic immigration papers. For example, many migrants initially obtain 


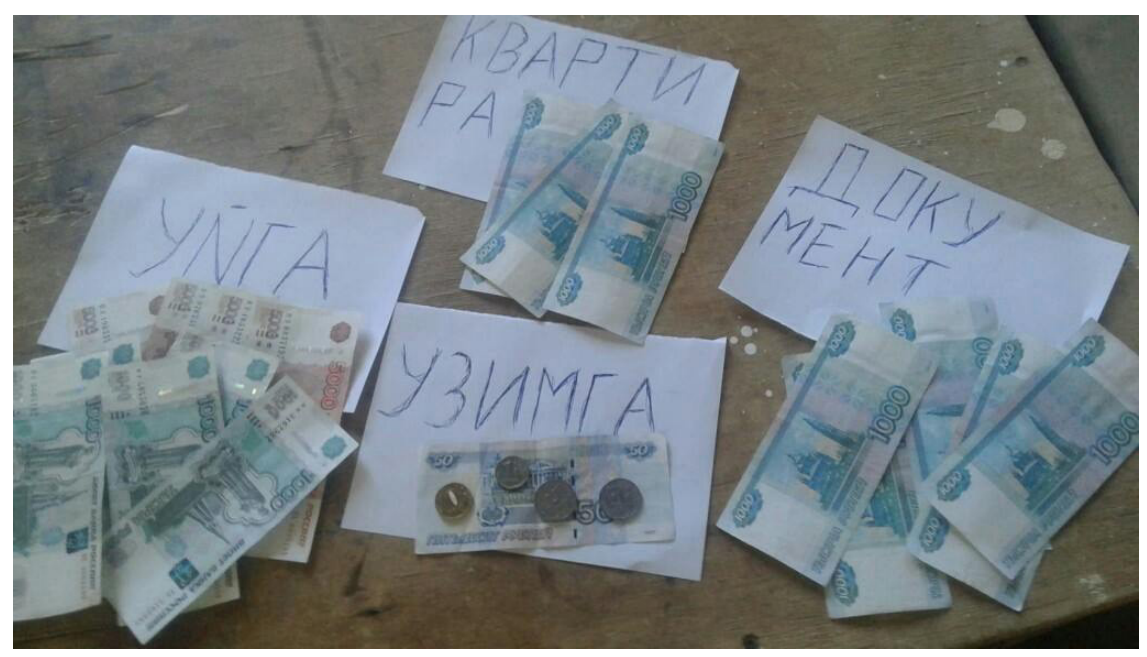

FIGURE 4. A migrant's monthly income is divided into four different expenses: sending money home (уйга), accommodation (квартира), monthly work-permit fee (документ), and meals and daily transportation (узимга) expenses. As a result, this migrant has only 71 rubles (US\$1) left for his monthly meals and transportation expenses. August 2016. Photo by author.

an authentic patent and work legally. But, after a few months and owing to the expensive monthly patent fee or delays in salary payment, migrants begin buying fake patent payment receipts from intermediaries at the Kazansky railway station. When stopped by police officers, migrants typically present these fake receipts. This strategy often works since police officers do not have the capacity to check the authenticity of various receipts. To discover whether receipts are authentic, police officers must send them to the tax department, a process that might take several days. Not wanting to engage in bureaucratic hassles, police officers usually let migrants go and, instead, target those "completely paperless" migrants not wellconnected to Kazansky intermediaries. These examples indicate that the Russian policies of migration control have produced additional undocumented migrants for the shadow economy rather than simplifying the procedures for legalizing the foreign labor force.

In addition, the efficiency of entry bans as a migration management tool remains questionable. Following the legislative changes made on July 23, 2013, migrants who committed two or more administrative offenses began receiving a three-year entry ban. As a result, migrants banned from entry were prevented from extending or renewing their immigration papers and were required to leave the Russian territory as soon as possible (Kubal 2016a). In mid-2016 Olga Kirillova, head of the General Administration for Migration Issues of the Ministry of the Interior of Russia, reported that the total number of foreign citizens banned from entry approached 2 million people (Interfax 2016). The vast majority of these migrants 
were citizens of Tajikistan and Uzbekistan (Troitskii 2016). But no evidence showed that these measures produced the desired effect. A small decrease in the number of migrants resulted more from the recession in Russia in autumn of 2014, causing a drop in jobs and incomes, than from demonstrating the effectiveness of prohibitive measures (Abashin 2016). Thus, rather than reducing the number of undocumented migrants, these legal restrictions and punitive measures further contributed to the growth of the shadow economy. Migrants learned to sidestep restrictions by buying "new passports" or "clean fake" immigration papers from the numerous "legalizing firms" operating in Russia (Reeves 2013; Dave 2014a). They also limited their return trips home and concentrated instead on one long stay, during which they attempted to earn as much as possible, knowing that this might be the only opportunity they would have for a long time. Hence, the frequency of border crossings decreased, and many entry-banned migrants began overstaying in Russia without valid documents, thereby increasing the share of undocumented migrants in the labor market. This trend was apparently confirmed by official statistics, showing that nearly 3 million foreign nationals in Russia had already violated the legal terms of their stay (Pochuev 2015).

Another factor that pushed migrants toward "illegality" was the gap between legal decisions and deficiencies, as well as uncertainties in bureaucratic practices. The monthly patent payment serves as a relevant example. Migrants are required to pay a patent fee by the last day of each month; failure to do so leads to annulment of the patent. This requirement creates obstacles during holidays, especially during the New Year holidays, when Russians take a break until January 10. In Russia many legislative and administrative changes enter into force from January 1 , including the budget classification code $(\mathrm{KBK})$, which needs to be entered into an automatic payment terminal when paying in to the state budget. Simply put, migrants need to enter the correct KBK code when paying their monthly patent fee. Given that Russian state institutions are closed until January 10, migrants cannot access a new KBK code from the authorities and, hence, are unable to pay the patent fee on time, resulting in the annulment of their patent. Given these bureaucratic deficiencies, many migrants become "illegal" and are, therefore, forced to resort to the shadow economy. However, these bureaucratic deficiencies may also empower migrants. As mentioned earlier, entry-banned migrants remain within Russia since they are aware that they might not be allowed to reenter if they leave the country. Owing to the existence of extensive information channels among different migrant networks, many migrants have learned that they can actually remain and work in Russia illegally until their entry ban expires. After the expiration of their entry ban, migrants leave Russia and reenter with a new migration card, allowing them to begin another "migration adventure." Most migrants even receive a patent and residence registration. Yet these strategies remain short-term, and sooner or later Russian migration officials detect these infractions and issue new entry bans on migrants who overstayed during previous visits. Because of the massive number of such infractions, it may take several months or even a year for 
the Russian authorities to detect them. These assumptions are confirmed by the 2016 statistics, which show that, from the nearly 4 million foreign citizens listing their purpose of entry to Russia as "work" on their migration card, only 1.5 million received a patent, indicating that 2.5 million migrants remained in Russia illegally. ${ }^{5}$ The above examples, thus, suggest that a close relationship between bureaucratic deficiencies and uncertainties exists, resulting in the growth of the shadow economy around labor migration.

At first glance, an analysis of Russian immigration laws and policies gives the impression of an inconsistent and chaotic process rather than a rational strategy aimed at combating illegal migration (see Mukomel 2012; Dave 2014a; Malakhov 2014; Abashin 2016). Abashin (2016) explains these inconsistencies by referring to the conflicting attitudes and ideological differences between various actors and lobby groups (liberals, conditional siloviks, nationalists, and neoimperialists) that struggle to push their own views regarding labor migration regulations. On the one hand, labor migration is viewed as inevitable and even necessary to address economic and demographic needs. On the other hand, migration represents a dangerous and undesirable phenomenon from a security and cultural perspective. In reality the driving logic behind constantly changing immigration laws relies on establishing a standard for distinguishing "us vs. alien" and "preferred vs. nonpreferred migrants." This logic is reflected both in antimigrant attitudes within society and official reactions and rhetoric within government circles. Given these conflicting views, it is unsurprising that liberal immigration rules existed alongside conservative measures (Malakhov 2014). In Abashin's (2016) view, the combination of these conflicting attitudes, discourse segmentation, and ideological polarization ultimately rendered Russian migration policy incoherent and volatile. But Reeves (2015) argues that these legal inconsistencies and ambiguities should not be viewed as a sign of state weakness or the failure of migration policies. In Russia, migration governance relies less on an integrated and purposive regime than on the proliferation of ambiguous spaces resulting from inconsistencies among the legal environment, administrative regulation, and the labor market. In addition, Schenk (2018) maintains that these legal ambiguities should be viewed as key features of migration governance since they produce low numbers of documented migrants that can be deployed as a powerful populist tool to satisfy antimigrant sentiments, as well as a source of kormushka (a Russian metaphor used to describe corrupt practices) by mid- and low-level state officials eager to generate informal benefits from a large army of undocumented migrants. Viewed in this way, the seeming inconsistency of the Russian migration policy provides a rational explanation and reflects the functioning of contemporary Russia's entire bureaucratic machine, which relies on Soviet-era governance techniques, as well as the material interests of state officials at all levels (Malakhov and Simon 2017).

Given the resistance of the sistema in Russian politics (Ledeneva 2013), it is unsurprising that efforts to liberalize it through, for instance, simplifying the legalization of foreign workers, have remained contradictory and incoherent (Malakhov and 
Simon 2017). It has become quite common among migration experts to characterize the development trajectories of the Russian migration regime as a process of "one step forward, two steps backward" (Nikiforova and Brednikova 2018). The analysis of immigration laws and policies over the last two decades shows that whenever liberal laws appear in the migration legislation, they are immediately followed by restrictive amendments and bureaucratic obstacles that prevent migrants from legalizing their work and residence status (Abashin 2016; Malakhov and Simon 2017). Even the abolition of the quota system and the introduction of a single patent system for CIS migrants did not facilitate migrant legalization. Malakhov and Simon (2017) explain that the Russian migration regime functions through the persistence of a Soviet-era administrative culture. In this way governance is understood as imposing restrictions and prohibitions rather than encouraging and fostering society's self-organizing units. Thus, arbitrariness and restriction are embedded in the very logic of the legal system's functioning. The ramifications of this approach to migration governance mean that Russian officials understand immigration regulations not as a tool to facilitate migrants' general compliance with the law but rather as an instrument to discipline and punish migrants who fail to obey the law (Kubal 2016b). In addition, this approach provides an opportunity to generate material benefits for certain groups and officials (Malakhov 2014; Schenk 2018). Given these legal and bureaucratic uncertainties, informal practices and channels within the shadow economy become alternative means for migrant legal adaptation. In other words, the legal adaptation of migrants to the Russian context takes place through navigating the corrupt and inconsistent legal environment, adapting to "street laws" (ko'cha qonunlari), and mastering various semilegal or illegal practices within the shadow economy.

\section{IMPLICATIONS FOR MIGRANT LEGAL ADAPTATION}

As shown in the previous sections, the Russian migration regime is characterized by a large shadow economy predicated on a massive undocumented migrant labor force. In this sense lack of documentation is not the exception but rather a way of life for millions of migrants in Russia. The large-scale presence of Central Asian migrants on the streets of Russian cities provoked public discord and led to widespread antimigrant sentiments in Russian society (Abashin 2016). The ongoing demographic crisis further contributes to the growth of antimigrant attitudes. Because the Russian population has been declining since the 1990s, fear exists among Russians that non-Russians will become the majority of the population by 2050 (Marat 2009). Additionally, migrants experience racism across all social settings and everyday situations, in their interactions with migration officials, police officers, or border guards. A 2016 survey conducted by the Levada Center found that the majority of Russians ( 52 percent) agreed with the statement, "Russia for ethnic Russians," and nearly 70 percent of respondents thought that the 
government should restrict the influx of Central Asian migrants and that undocumented migrants should be expelled from Russia (Pipia 2016). Such negative attitudes toward Central Asian workers existed even during Soviet times despite the popular druzhba narodov (people's friendship) discourse. Central Asians working on construction sites (limitchiki) in Moscow and Leningrad were perceived as chernye (black) and faced discrimination (Sahadeo 2007). These antimigrant sentiments are used strategically by Russian politicians to gain popular support during elections. For example, the Moscow mayoral election in the summer of 2013 became the first political event in Russia during which migration represented one of the most intensely discussed topics during the preelection campaign (Abashin 2016). Despite their varying orientations and agendas, every candidate's campaign featured a strong antimigrant sentiment, proposing the introduction of more repressive migration controls. That campaign strategy was specifically dominated by the antimigrant speeches of the acting mayor, Sergey Sobyanin, who insisted that migrants should not attempt to settle in Moscow but rather should return home immediately after finishing their temporary work (Kingsbury 2017). These preelection campaigns further contributed to the spike in antimigrant sentiments in an already xenophobic Russian society.

The prevalence of such sentiments can also be explained by the biased portrayals of Central Asian migrants as "illegals" (nelegaly) or gastarbaitery (from the German word Gastarbeiter) used by the Russian mass media (Kuznetsova and Round 2018). Although the word migrant is not used at all in Russian immigration laws, the media and politicians gradually developed an informal definition of the term by referring to migrant workers from Central Asian countries that have a visa-free agreement with Russia (Abashin 2016). The legal categories introduced in the "Law on the Legal Status of Foreign Citizens in the Russian Federation" remain vague and do not explicitly mention the ethnicity of a foreign citizen: "A foreign citizen who arrived in the Russian Federation in accordance with the regulation who does not require a visa." Kondakov's (2017) analysis of Russian newspaper articles shows that following the introduction of new legal categories through the law, such categories then also appeared in newspapers, where they were reinterpreted in a more explicit manner. For example, Kondakov focused on Rossiiskaya Gazeta, which began using such categories as bezvizoviki (visa-free migrants) and "Central Asian migrants" interchangeably in 2006 and 2007. As Kondakov concludes, the legally designated "visa-free visitor" represents a racist definition of Central Asian migrants working in unprivileged and precarious jobs. This perspective is also reinforced by Demintseva (2019), who argued that in everyday life in Russia a migrant is defined as a person who does not look Russian, regardless of his or her legal status, citizenship, or period of residence. These racist media constructions shape public opinion and intensify xenophobic and pejorative attitudes toward migrants. 
The rise of antimigrant attitudes also associates with the absence of formal migrant integration policies in Russia (Brednikova and Tkach 2010; Gorenburg 2014; Malakhov 2015). There is no educational infrastructure enabling migrants to acquire the skills necessary to adapt nor any state agency charged with the question of integrating and adapting migrants (Streltsova 2014). The Main Directorate for Migration Affairs (formerly FMS), part of the Ministry of Internal Affairs, primarily serves as a law-enforcement structure and is mainly concerned not with ensuring the rational regulation of labor migration but with issuing documents and taking punitive measures in relation to migrants who fail to obtain a patent. While Russia's Migration 2025 Concept highlights the need to integrate migrants, in reality it views migrants as cultural "others" requiring assimilation by erasing their cultural differences and norms of conduct (Kondakov 2017). Migrant adaptation problems, including the fact that many migrants are forced to work in the shadow economy, are explained as resulting from their premigratory cultural repertoires rather than as an outcome of structural barriers (Shnirel'man 2008). A strong belief within government circles argues against migrants bringing their legal cultures and ways of life to Russia and preparing them to face challenges. ${ }^{6}$ In Russia migrant adaptation is thus understood as depriving migrants of their culture and traditions and forcing them to adopt the Russian culture. ${ }^{7}$ Accordingly, in public discussions, as well as in policy documents, Russian authorities typically emphasize the cultural integration of migrants, while their economic, social, legal, and political adaptation is neglected (Aitamurto 2016). Consequently, alienation from Russian society is more common than adaptation or integration (Mukomel 2012; Yusupova and Ponarin 2016). Although migrants may live in an apartment building with local Russian citizens, the migrants barely enter into closer contact with the "native" inhabitants of their apartment building or their quarters (Demintseva 2017). Communication also remains limited in workplace settings. Many migrant workers work, live, and socialize in special industrial areas, bazaars, and ethnic cafés where few local Russian people enter. One study (though rather dated) conducted by Tyuryukanova (2008) found that only 8 percent of all Central Asian migrant laborers worked in jobs primarily consisting of Russian employees, whereas 60 percent of migrants worked in migrant environments, and about 30 percent worked in mixed environments.

The absence of a clearly thought-through migration policy can also be explained by the tendency to view Central Asian labor migration as a temporary phenomenon (Bisson 2016). As Nikiforova and Brednikova (2018) note, both the state and migrants are deluded by the illusion of temporariness. The state neglects the fact that Central Asian labor migration represents a permanent phenomenon, which deserves adequate attention in its migration policy. Migrants are also under the delusion that their stay in Russia is temporary and that they will eventually return to their home countries. This illusion of temporariness, shared by the state and migrants, sets the terms of existence for all those occupying the migration space 
and impedes any possibilities for integration (Nikiforova and Brednikova 2018). Because migrants are viewed as temporary cheap labor, they operate in a precarious position and are excluded from the state and social structures such as health care, education, and social support (Kuznetsova and Round 2018). Thus, Russian migration policy does not facilitate the legalization and adaptation of Central Asian migrants but rather orients them toward the creation of unbearable conditions so that fewer migrants enter Russia. This thinking is particularly visible in the words of the head of the Federation of Migrants of Russia: "If the person is coming to Russia for work, he must understand and be prepared that his life will be very difficult here. He must never think that he will live like a local here. He must understand that by making a decision to work in Russia he made a difficult choice in his life. If he wants to change his life, he must be ready to pay the price."

Experiencing racism is thus a part of migrants' everyday life in Russia. Central Asian migrants serve as scapegoats, used by the Russian regime to divert the local population's attention away from domestic social problems, such as corruption, the lack of democratic freedoms, and economic stagnation (Kingsbury 2017). Migrants experience difficult living and working conditions and typically work informally, without a formal employment contract (Human Rights Watch 2009; Zabyelina 2016). Given that the majority of migrants remain undocumented and work in the shadow economy, Russian employers and intermediaries have a strong incentive to exploit migrants and withhold or delay their salaries. Employers understand that transactions completed in the shadow economy-in violation of labor regulations or tax codes-cannot be heard in state courts according to the Russian Civil Code (Urinboyev and Polese 2016). Moreover, migrants remain reluctant to approach state institutions, since doing so would reveal their undocumented status and invite punishment by the state. Even those migrants who possess all of the required papers and work legally cannot be certain that they will be paid for their work. A recent scandal connected with a subway construction project in Moscow serves as a good example. In this case the Tajik and Uzbek migrant workers who built the subway were not paid for five months. Migrants gathered near the office of the Ingeocom construction company demanding their unpaid salaries. But the company management said that the workers did not have the right to strike, since they were not citizens of the Russian Federation (Moscow Times 2017). Central Asian migrants also experience hardships in finding accommodation as a result of the anti-immigrant sentiment prevailing within society and the reluctance of property owners to let apartments to "non-Russians," even when migrants have the financial means to rent a separate room or apartment (Demintseva 2017). In addition, migrants must deal with corrupt police officers who regularly extort money from them (Light 2016; Round and Kuznetsova 2016). Today, anyone walking on the streets of large Russian cities (e.g., Moscow, Saint Petersburg, Yekaterinburg) will quickly notice police officers checking the documents of Central Asian and Caucasian migrants. This is particularly visible on the 
Moscow metro, where police officers frequently stand at the top of escalators to stop migrants (Round and Kuznetsova 2016).

Accordingly, the general political situation in Russia does not allow migrants to approach formal institutions for redress, and they remain completely vulnerable to the whims of their employers (Laruelle 2007). Precious few civil society organizations and migrant rights activists in Russia are available for migrants to approach for protection (Korobkov 2007; Matusevich 2015). While diaspora groups in Russia are assumed to be the first port of call for migrants seeking assistance, the role and usefulness of such groups in migrants' lives is quite limited (Varshaver and Rocheva 2014; Berg-Nordlie and Tkach 2016). Media reports indicate that some members of Central Asian diaspora groups have actually facilitated the exploitation of migrant workers, at times acting as intermediaries between abusive employers and potential migrants (Fergananews.com 2016; Ozodlik Radiosi 2016). Furthermore, the capacity of civil society groups to provide support to migrants is quite limited given the continued persecution of nongovernmental organizations in Russia (Kuznetsova and Round 2018). A rare example of an effective civil society organization is "Tong Jahoni," a migrant rights organization led by prominent migrant rights lawyer and activist Valentina Chupik, who deals with several thousand cases involving Central Asian migrants. It is important to recognize, however, that resources and the reach of civil society institutions are rather limited given the "foreign agent" law. Therefore, the majority of migrants rely on their transnational networks, kinship groups, and informal social safety nets to organize their precarious livelihoods.

Thus, the everyday life of migrant workers in Russia is characterized by a constant sense of insecurity, threatened by exploitation, deportation, police corruption, racism, physical violence, and even death. The unrule-of-law environment dominates, and a legal or illegal status hinges on contextual factors and the individual's skills. Shadow economy employment remains the rule for many migrants, with little or no room for collectively mobilizing migrants. Despite these hardships, the possibility of working in Russia, from the perspective of migrants, provides a vital economic lifeline for their families back home, leading them to accept everyday injustices, exploitation, and racism (Matusevich 2015).

It is important to realize, however, that Central Asian migrants are not merely passive, agencyless subjects constrained by structural barriers but are capable of inventing various informal strategies to organize their precarious livelihoods. This complete lack of security compelled Central Asian migrants to create informal networks and migrant-concentrated areas and structures to cope with the risks and uncertainties of their ambiguous situations (Zabyelina 2016; Urinboyev 2017b). Such migrant-concentrated areas occupy a fixed spatial location, often situated in areas around bazaars and wholesale markets (Light 2010). The wholesale food bazaar "Food City" in Moscow's Kaluzhskoe shosse serves as one such "migrant enclave," where migrants created an informal infrastructure with its own informal 
"legal order" and governance structure. These migrant areas and the networks revolving around them serve as an alternative means to integrate and provide adaptation mechanisms for many migrants, granting access to basic public goods, such as jobs, housing, and physical and economic security. Such networks typically revolve around the bonds of kinship, region of origin, or ethnic affiliation, reproducing many "domestic" practices adapted to the conditions of migration and temporary residence (Abashin 2014; Urinboyev 2016). The existence of an informal infrastructure allows migrants to adapt in some ways to an otherwise restrictive legal environment, such as by devising specific survival strategies, creating intragroup solidarity, distributing information about jobs, and building up an informal social safety net to minimize risks to livelihoods and deal with emergency situations (e.g., medical treatment, repatriation of decedents to their home country, and so on). These networks, possessing their own infrastructure of trust, mutual aid, and social services (e.g., Kyrgyz clinic, Uzbek cafés, etc.), constitute an important social safety net for migrants (Matusevich 2015; Urinboyev and Polese 2016; Demintseva 2017). Some commentators refer to such migrant networks as Uzbekskiy Peterburg (Yakimov 2015), Kyrgyztown (Varshaver et al. 2014), and Moskvaobod (BBC Uzbek 2012). Hence, the distinctive feature of the Russian migration regime is the presence of a hidden world of migrants based on its own economy, a virtual platform, a legal order, and a welfare infrastructure. A "thick description" of these processes appears in the chapters that follow. 